\title{
Optimasi Pertumbuhan Vegetatif dan Keragaan Tanaman Jeruk Keprok Borneo Prima (Citrus reticulata cv. Borneo Prima) melalui Pemangkasan dan Pemupukan
}

\author{
Optimizing Vegetatif Growth and Trees Architecture of Mandarin Citrus Plants cv. Borneo \\ Prima (Citrus reticulata cv. Borneo Prima) by Pruning and Fertilization
}

\author{
Resa Sri Rahayu ${ }^{1}$ dan Roedhy Poerwanto ${ }^{1 *}$ \\ Diterima 10 Juni 2014/Disetujui 23 Juli 2014
}

\begin{abstract}
Mandarin citrus $c v$. Borneo Prima is superior local commodity that needs to be expaned for reduction of citrus import. Development of the commodity needs to follow good agricultural practice to optimize growth. The objectives of this research were to optimize vegetative growth and tree architecture of mandarin citrus cv. Borneo Prima by various dosages of nitrogen fertilizer and pruning. This research used Randomize Complete Block Design (RCBD) with two factors. The first factor was various dosage of nitrogen fertilizer consisting of four levels: $0 \mathrm{~g}(P 0), 10 \mathrm{~g}(\mathrm{Pl}), 20 \mathrm{~g}$ $(P 2)$, and $30 \mathrm{~g}(P 3)$. The second factor was pruning shape consisting of three levels: no pruning $(K 1)$, open center pruning (K2), and hedge pruning (K3). The results showed that dosages of nitrogen fertilizer did not give significant effect variables of vegetative growth and plant architecture except for Leaf Area Index (LAI). Pruning had significant effect to variables of vegetative growth and plant architecture. Hedge pruning and open center pruning were significantly different from no pruning treatment on tree architecture's by expanding canopy surface to absorb sunlight. Interaction between nitrogen fertilizer dosages and pruning shapes were not significant.
\end{abstract}

Keywords: canopy surface, hegde pruning, mandarin citrus cv. Borneo Prima, vegetatif growth

\begin{abstract}
ABSTRAK
Jeruk keprok Borneo Prima merupakan komoditas lokal unggulan yang perlu dikembangkan sebagai upaya untuk mengurangi impor jeruk. Pengembangan jeruk ini harus memperhatikan teknik budi daya yang baik untuk mengoptimalkan pertumbuhan. Tujuan penelitian ini adalah mengoptimalkan pertumbuhan vegetatif dan keragaan tanaman jeruk keprok Borneo Prima melalui berbagai dosis pupuk nitrogen dan bentuk pemangkasan. Kegiatan penelitian ini menggunakan Rancangan Kelompok Lengkap Teracak (RKLT) faktorial dengan dua faktor. Faktor pertama adalah dosis pupuk nitrogen yang terdiri atas empat taraf: $0 \mathrm{~g}(\mathrm{P} 0), 10 \mathrm{~g}$ (P1), $20 \mathrm{~g}(\mathrm{P} 2)$, dan $30 \mathrm{~g}$ (P3) pertanaman. Faktor kedua adalah bentuk pemangkasan yang terdiri atas tiga taraf: tanpa pemangkasan (K1), pangkas terbuka tengah (K2), dan pangkas pagar (K3). Hasil penelitian menunjukkan bahwa dosis pupuk nitrogen tidak memberikan pengaruh yang nyata terhadap peubahpeubah pertumbuhan vegetatif dan keragaan tanaman kecuali Indeks Luas Daun (ILD). Bentuk pemangkasan memberikan pengaruh yang nyata terhadap peubah-peubah pertumbuhan vegetatif dan keragaan tanaman. Perlakuan pangkas pagar dan pangkas terbuka tengah berbeda nyata dengan perlakuan tanpa pemangkasan terhadap bentuk keragaan tanaman dengan memperluas permukaan kanopi untuk menyerap cahaya matahari. Tidak ada interaksi antara dosis pupuk nitrogen dan bentuk pemangkasan.
\end{abstract}

Kata kunci: jeruk keprok Borneo Prima, pangkas pagar, permukaan kanopi, pertumbuhan vegetatif, pangkas terbuka tengah

${ }^{1}$ Departemen Agronomi dan Hortikultura, Fakultas Pertanian, Institut Pertanian Bogor

(Bogor Agricultural University), J1. Meranti, Kampus IPB Darmaga, Bogor 16680, Indonesia

Telp.\&Faks.62-251-8629353 e-mail: roedhy8@yahoo.co.id (*penulis korespondensi) 


\section{PENDAHULUAN}

Jeruk merupakan salah satu buah yang banyak dikonsumsi masyarakat Indonesia dalam bentuk segar. Produksi jeruk lokal telah memenuhi permintaan jeruk nasional, namun impor jeruk tetap dilakukan karena beberapa golongan masyarakat menginginkan kualitas jeruk seperti jeruk impor yang salah satunya adalah berwarna kulit kuning-jingga. Pada tahun 2012, produksi jeruk nasional sebanyak 1611784 ton (BPS, 2014) dengan jumlah konsumsi sebanyak 635720 ton (Pusat Data dan Sistem Informasi Pertanian, 2013), namun Indonesia masih mengimpor jeruk sebanyak 179000 ton (BPS, 2013). Jeruk dengan warna kulit kuning-jingga sebagian besar dihasilkan di daerah dataran tinggi. Hal tersebut menjadi kendala karena luas lahan dataran tinggi di Indonesia sangat terbatas dan penggunaannya bersaing dengan tanaman hortikultura lain. Keadaan tersebut perlu diatasi dengan mengintroduksi varietas jeruk dataran rendah yang berwarna kulit kuning-jingga. Tahun 2007, Departemen Pertanian melepas varietas baru jeruk keprok dengan nama jeruk keprok Borneo Prima (Citrus reticulata cv. Borneo Prima) yang merupakan varietas jeruk dataran rendah dengan karakteristik unggul yaitu buahnya berwarna jingga seperti varietas jeruk dataran tinggi (Warta Prima, 2007).

Menurut Badan Perumahan dan Penanaman Modal Daerah (BPPMD) Provinsi Kalimantan Timur (2009), jeruk keprok Borneo Prima mulai dikembangkan sejak tahun 2006. Tindakan budi daya yang tepat perlu dilakukan untuk mengoptimalkan pertumbuhan jeruk keprok Borneo Prima. Salah satu tindakan budi daya yang sangat penting adalah pemupukan tanaman yang disesuaikan dengan kebutuhan dan umur tanaman. Tanaman jeruk belum menghasilkan (LTBM) memerlukan pertumbuhan vegetatif yang optimal sehingga pemupukan lebih difokuskan untuk mengoptimalkan petumbuhan vegetatif. Penelitian Dewi et al. (2014) menunjukkan bahwa jeruk besar dapat dikonservasi secara in vitro dan menunjukkan respon pertumbuhan yang berbeda melalui zat pengatur tumbuh. Menurut Gardner et al. (2008), berlangsungnya pertumbuhan vegetatif terutama ditentukan oleh air dan nitrogen sehingga pemupukan difokuskan pada nitrogen. Perbaikan bentuk keragaan tanaman atau bentuk arsitektur pohon perlu diperhatikan untuk menjamin penangkapan cahaya matahari yang optimal sehingga pertumbuhan tanaman jeruk optimal. Bentuk pemeliharaan pohon yang dilakukan untuk pembentukan keragaan tanaman adalah pemangkasan bentuk.

Berdasarkan permasalahan tersebut, penelitian ini bertujuan mencari kombinasi terbaik antara dosis pupuk nitogen dengan bentuk pemangkasan untuk mengoptimalkan pertumbuhan vegetatif dan keragaan tanaman serta melihat pengaruhnya masing-masing terhadap pertumbuhan vegetatif dan keragaan tanaman jeruk keprok Borneo Prima.

\section{BAHAN DAN METODE}

Penelitian ini dilaksanakan di Kebun Percobaan Institut Pertanian Bogor Sindangbarang, Desa Sindangbarang, Kecamatan Bogor Barat, Kota Bogor, Jawa Barat, pada Bulan Januari hingga Mei 2014. Tanaman jeruk keprok Borneo Prima yang digunakan adalah tanaman jeruk hasil okulasi dari batang bawah Japanese citrus (JC) dan batang atas jeruk lokal Kalimantan. Jeruk tersebut didatangkan langsung dari Kalimantan. Umur tanaman saat perlakuan adalah satu tahun.

Rancangan yang digunakan dalam penelitian ini adalah Rancangan Kelompok Lengkap Teracak (RKLT) faktorial dengan dua perlakuan yaitu dosis pupuk nitrogen $(\mathrm{N})$ dan jenis pemangkasan bentuk. Perlakuan dosis pupuk nitrogen terdiri atas empat taraf yaitu dosis pupuk $\mathrm{N}$ di atas standar rekomendasi (30 gram $\mathrm{N}$ per pohon), sesuai standar rekomendasi (20 gram $\mathrm{N}$ per pohon), di bawah standar rekomendasi (10 gram $\mathrm{N}$ per pohon), dan tanpa pemupukan N. Perlakuan jenis pemangkasan bentuk terdiri atas tiga taraf yaitu pangkas terbuka tengah, pangkas pagar, dan tanpa pemangkasan. Kombinasi antar perlakuan dalam penelitian ini adalah sebanyak 12 kombinasi dengan empat ulangan sehingga terdapat 48 satuan percobaan dengan total tanaman jeruk yang diamati sebanyak 48 tanaman.

Kegiatan penelitian dimulai dengan mempersiapkan dan menentukan sampel tanaman yang akan mendapat perlakuan pemangkasan dan pemupukan nitrogen. Setelah sampel tanaman ditentukan, tanaman sampel dipangkas sesuai perlakuan dan selanjutnya diberi pupuk urea $(45 \% \mathrm{~N})$ sesuai perlakuan, pupuk SP36 $\left(36 \% \mathrm{P}_{2} \mathrm{O}_{5}\right)$ sebanyak $28 \mathrm{~g}$ per pohon, dan pupuk $\mathrm{KCl}\left(60 \% \mathrm{~K}_{2} \mathrm{O}\right)$ 
sebanyak 9 g per pohon. Pupuk SP36 dan $\mathrm{KCl}$ diberikan dengan dosis yang sama untuk semua tanaman contoh. Kegiatan selanjutnya adalah analisis tanah yang bertujuan untuk mengetahui kandungan unsur hara tanah setelah dilakukan pemupukan. Informasi dari hasil analisis tanah tersebut menjadi referensi penting dalam pengambilan kesimpulan penelitian.

Pengamatan dilakukan setelah pemangkasan dan aplikasi pemupukan dengan mengamati waktu muncul tunas, waktu berhentinya pertumbuhan tunas (dorman), waktu muncul tunas berikutnya, lama periode tunas, lama masa dorman, panjang tunas, jumlah tunas, jumlah daun tiap tunas, luas daun (meng-gunakan leaf area meter), tinggi tanaman, tingkat kehijauan daun (menggunakan chlorophyll meter), jumlah daun, Indeks Luas Daun (ILD), panjang tajuk arah utara-selatan dan arah timur-barat serta pertambahan panjang tajuk arah utara-selatan dan arah timur-barat.

\section{HASIL DAN PEMBAHASAN}

\section{Pertumbuhan Vegetatif Waktu Muncul dan Berhenti Tunas}

Perlakuan pemupukan nitrogen tidak memberikan pengaruh yang nyata terhadap waktu muncul dan berhentinya tunas pada periode pertumbuhan tunas kedua. Waktu munculnya tunas-tunas baru tersebut berbeda pada setiap pohon dan sangat dipengaruhi oleh ketersediaan air dan cahaya matahari. Bulan
Januari sampai Mei saat penelitian merupakan bulan dengan curah yang tinggi dan pencahayaan matahari tinggi. Kondisi tersebut membuat tunas-tunas baru muncul serempak dan lebat pada semua tanaman. Perlakuan pemangkasan tidak memberikan pengaruh yang nyata pada waktu muncul tunas periode pertama, dan periode tunas kedua. Pemangkasan dapat mematahkan fase dormansi tunas-tunas ketiak daun dan tunas-tunas pada bagian ujung tanaman sehingga perlakuan pemangkasan akan mempercepat kemunculan tunas baru (Gardner et al., 2008).

\section{Lama Periode Tunas dan Lama Masa Dorman}

Tabel 1 menunjukkan bahwa perlakuan pemupukan nitrogen dan pemangkasan bentuk tidak memberikan pengaruh yang nyata dalam mempengaruhi lamanya periode tunas pada periode tunas pertama dan kedua serta masa dorman. Tingginya curah hujan selama pengamatan menyebabkan pupuk yang diaplikasikan pada tanaman jeruk kemungkinan besar tercuci. Curah hujan selama penelitan yaitu dari Januari sampai April berturut-turut adalah $702 \mathrm{~mm}$ (sangat tinggi), $337 \mathrm{~mm}$ (tinggi), $281 \mathrm{~mm}$ (menengah), dan $511 \mathrm{~mm}$ (sangat tinggi) (BMKG, 2014). Menurut Zaman et al. (2005) dan Hardjowigeno (2010), hujan yang tinggi menyebabkan nitrogen mudah tercuci dan mengalir ke daerah bawah perakaran sehingga empat dosis pupuk yang diberikan pada tanaman tidak berbeda nyata.

Tabel 1. Lama periode tunas dan masa dorman tunas tanaman jeruk keprok Borneo Prima pada dua periode pertumbuhan tunas

\begin{tabular}{|c|c|c|c|}
\hline \multirow[b]{2}{*}{ Perlakuan } & \multicolumn{3}{|c|}{ Lama periode tunas dan masa dormana } \\
\hline & tunas periode ke-1 & $\begin{array}{l}\text { dorman } \\
\text {....hari.... }\end{array}$ & $\begin{array}{l}\text { tunas periode ke-2 } \\
\text {... }\end{array}$ \\
\hline Pemupukan Nitrogen & & & \\
\hline Kontrol & $25.5 \mathrm{a}$ & $21.8 \mathrm{a}$ & $14.5 \mathrm{a}$ \\
\hline Di bawah standar rekomendasi $(10 \mathrm{~g} \mathrm{~N})$ & $24.3 \mathrm{a}$ & $21.8 \mathrm{a}$ & $15.0 \mathrm{a}$ \\
\hline Standar rekomendasi $(20 \mathrm{~g} \mathrm{~N})$ & $24.5 \mathrm{a}$ & $21.5 \mathrm{a}$ & $14.3 \mathrm{a}$ \\
\hline Di atas standar rekomendasi $(30 \mathrm{~g} \mathrm{~N})$ & $24.8 \mathrm{a}$ & $22.8 \mathrm{a}$ & $14.0 \mathrm{a}$ \\
\hline Pemangkasan & & & \\
\hline Kontrol & $25.3 \mathrm{a}$ & $22.1 \mathrm{a}$ & $13.9 \mathrm{a}$ \\
\hline Pangkas terbuka tengah & 24.6a & $21.9 \mathrm{a}$ & $14.4 \mathrm{a}$ \\
\hline Pangkas pagar & $24.4 \mathrm{a}$ & $21.9 \mathrm{a}$ & $15.0 \mathrm{a}$ \\
\hline Interaksi & tn & tn & tn \\
\hline
\end{tabular}

Keterangan: ${ }^{a}$ Angka-angka pada kolom yang sama yang diikuti oleh huruf yang sama tidak berbeda nyata pada taraf uji 5\% (uji Duncan's Multiple Range Test) $\mathrm{tn}=$ tidak berbeda nyata pada taraf 5\% uji DMRT 


\section{Panjang Tunas}

Hasil pengamatan menunjukkan bahwa perlakuan pemupukan nitrogen tidak memberikan pengaruh yang nyata terhadap panjang tunas pada periode pertumbuhan tunas pertama dan kedua. Pemangkasan memberikan pengaruh yang nyata pada periode tunas pertama, namun tidak memberikan pengaruh yang nyata terhadap panjang tunas pada periode tunas kedua. Perlakuan kontrol memberikan pengaruh paling tinggi terhadap panjang tunas yaitu dengan panjang tunas 15.8 $\mathrm{cm}$. Tanaman yang tidak dipangkas memiliki bentuk tajuk yang lebih rimbun sehingga tunas-tunas dan daun-daun yang muncul akan saling menaungi satu sama lain. Menurut Gardner et al. (2008), ruas tanaman yang ternaungi lebih panjang dibandingkan yang tidak ternaungi sehingga tajuk akan lebih panjang.

Gambar 1 menunjukkan pola pertumbuhan tunas yang terlihat sebagai pola sigmoid. Periode tunas pertama terjadi pada hari ke-0 sampai hari ke-39, masa dorman pada hari ke39 sampai hari ke-60 dan periode tunas kedua pada hari ke-60 sampai hari ke-78. Gambar 1 di atas juga menunjukkan bahwa kontrol memiliki panjang tunas terpanjang sementara bentuk pangkas terbuka tengah dan pangkas pagar tidak berbeda nyata.

\section{Jumlah Daun Tiap Tunas}

Pada tabel 2 menunjukkan bahwa perlakuan pemupukan nitrogen dan perlakuan bentuk pemangkasan tidak memberikan pengaruh yang nyata terhadap jumlah daun tiap tunas kecuali perlakuan tanpa pemangkasan yang berbeda nyata pada periode tunas pertama. Hal tersebut menunjukkan hasil yang sama dengan pengaruh pemupukan nitrogen dan bentuk pemangkasan terhadap panjang tunas dan menunjukkan bahwa perlakuan tanpa pemangkasan memiliki panjang tunas terpanjang, namun jumlah daun tidak berbeda nyata dengan perlakuan lainnya pada periode tunas kedua.

Pertambahan jumlah daun (Gambar 2) lebih cepat berhenti dibandingkan pertambahan panjang tunas (Gambar 1). Pada periode tunas pertama, jumlah daun sudah tidak bertambah pada hari ke-21 sementara tunas terus tumbuh sampai hari ke-39. Hal yang sama terjadi pada periode kedua pertumbuhan tunas. Pertambahan daun berhenti lebih cepat dan daun akan bertambah tua bersamaan dengan pertumbuhan tunas.

Tabel 2. Panjang tunas, jumlah daun tiap tunas, dan jumlah tunas tanaman jeruk keprok Borneo Prima pada dua periode pertumbuhan tunas

\begin{tabular}{|c|c|c|c|c|c|c|}
\hline \multirow[t]{2}{*}{ Perlakuan } & \multicolumn{2}{|c|}{$\begin{array}{l}\text { Panjang tunas } \\
\text { pada periode } \\
\text { pertumbuhan } \\
\text { tunas ke- }{ }^{\mathrm{a}}(\mathrm{cm})\end{array}$} & \multicolumn{2}{|c|}{$\begin{array}{l}\text { Jumlah daun } \\
\text { tiap tunas pada } \\
\text { periode } \\
\text { pertumbuhan } \\
{\text { tunas } \mathrm{ke}^{\mathrm{a}}}^{\mathrm{a}}\end{array}$} & \multicolumn{2}{|c|}{$\begin{array}{l}\text { Jumlah tunas } \\
\text { pada periode } \\
\text { pertumbuhan } \\
\text { tunas ke- }{ }^{\text {a }}\end{array}$} \\
\hline & 1 & 2 & 1 & 2 & 1 & 2 \\
\hline \multicolumn{7}{|l|}{ Pemupukan Nitrogen } \\
\hline Kontrol & $9.5 \mathrm{a}$ & $4.7 \mathrm{a}$ & $7.4 \mathrm{a}$ & $4.2 \mathrm{a}$ & $47.1 \mathrm{a}$ & $32.9 \mathrm{a}$ \\
\hline Di bawah standar rekomendasi $(10 \mathrm{~g} \mathrm{~N})$ & $11.7 \mathrm{a}$ & $5.2 \mathrm{a}$ & $7.8 \mathrm{a}$ & $3.9 \mathrm{a}$ & $40.8 \mathrm{a}$ & $36.8 \mathrm{a}$ \\
\hline Standar rekomendasi $(20 \mathrm{~g} \mathrm{~N})$ & $8.8 \mathrm{a}$ & $4.1 \mathrm{a}$ & 7.1a & $3.7 \mathrm{a}$ & $41.5 \mathrm{a}$ & $37.4 \mathrm{a}$ \\
\hline Di atas standar rekomendasi $(30 \mathrm{~g} \mathrm{~N})$ & $9.8 \mathrm{a}$ & $4.3 \mathrm{a}$ & $7.6 \mathrm{a}$ & $3.5 \mathrm{a}$ & $45.8 \mathrm{a}$ & $30.6 \mathrm{a}$ \\
\hline \multicolumn{7}{|l|}{ Pemangkasan } \\
\hline Kontrol & $15.8 \mathrm{a}$ & $4.3 \mathrm{a}$ & $9.7 \mathrm{a}$ & $3.3 \mathrm{a}$ & $61.1 \mathrm{a}$ & $29.5 \mathrm{a}$ \\
\hline Pangkas terbuka tengah & $8.0 \mathrm{~b}$ & $4.0 \mathrm{a}$ & $6.9 \mathrm{~b}$ & $3.6 \mathrm{a}$ & $37.6 \mathrm{~b}$ & $37.7 \mathrm{a}$ \\
\hline Pangkas pagar & $6.1 b$ & $5.4 \mathrm{a}$ & $5.9 \mathrm{~b}$ & $4.5 \mathrm{a}$ & $32.7 \mathrm{~b}$ & $36.1 \mathrm{a}$ \\
\hline Interaksi & $\operatorname{tn}$ & tn & tn & tn & $\operatorname{tn}$ & tn \\
\hline
\end{tabular}




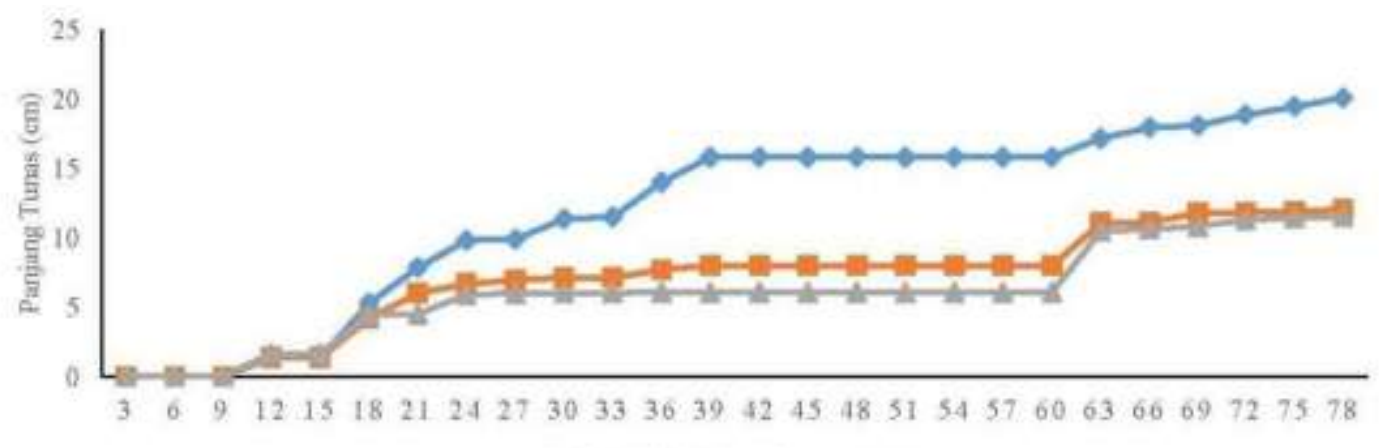

Hari Seteluh Pernangkasan (HSP)

Gambar 1 Pengaruh perlakuan pemangkasan terhadap pertambahan panjang tunas jeruk keprok Borneo Prima. - Kontrol, - II- Pangkas terbuka tengah, $\rightarrow$ Pangkas pagar

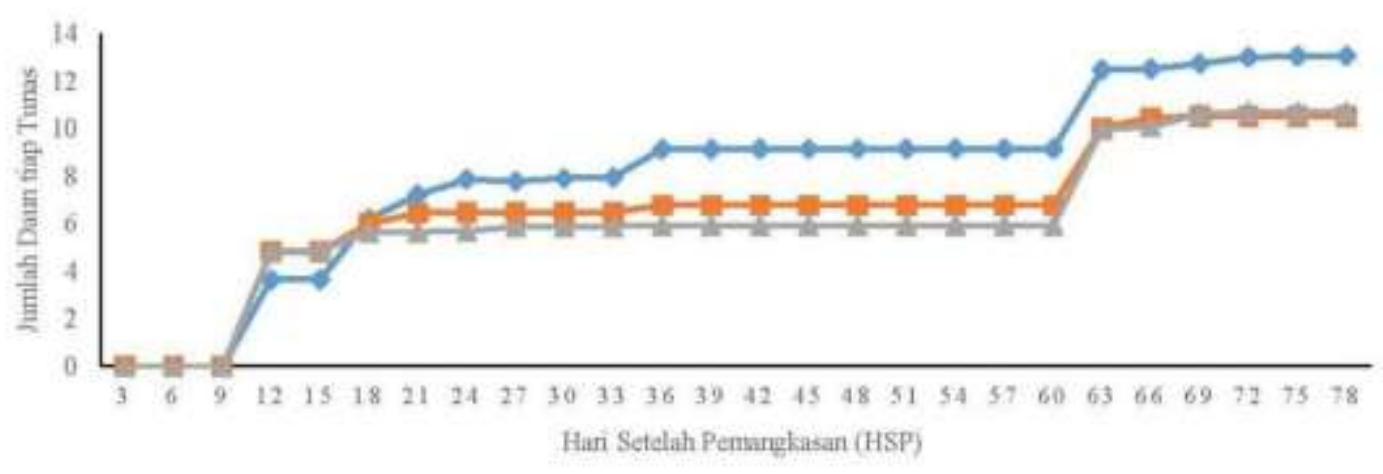

Gambar 2 Pengaruh perlakuan pemangkasan terhadap pertambahan jumlah daun tiap tunas jeruk keprok Bomeo Prima. - Kontrol, - $=$ - Pangkas terbuka tengah, - Pangkas pagar

\section{Jumlah Tunas}

Tabel 2 menunjukkan bahwa pada periode tunas pertama, tanaman yang tidak dipangkas memiliki tunas-tunas baru yang lebih banyak dan berbeda nyata dengan tanaman yang dipangkas. Hal ini disebabkan karena tanaman yang tidak dipangkas memiliki jumlah daun yang lebih banyak dan kemungkinan besar tunas-tunas baru muncul dari ketiak daun. Jeruk menghasilkan beberapa percabangan dari satu ketiak sehingga akan menghasilkan banyak percabangan. Menurut Gardner et al. (2008), hal tersebut mempengaruhi jumlah tunas pada tanaman yang tidak dipangkas.

Pada periode kedua, perlakuan bentuk pemangkasan tidak memberikan pengaruh yang nyata terhadap jumlah tunas yang muncul. Pada periode kedua, jumlah daun pada tiap tanaman bertambah dan memungkinkan untuk memunculkan tunas-tunas baru dari ketiak daunnya sehingga jumlah tunas pada semua tanaman contoh baik yang dipangkas maupun yang tidak dipangkas tidak berbeda nyata.

Pemupukan nitrogen tidak memberikan pengaruh yang nyata terhadap jumlah tunas yang muncul di kedua periode tunas. Selama kegiatan penelitian berlangsung, diduga pupuk yang telah diaplikasikan tercuci karena curah hujan yang tinggi sehingga tidak memberikan pengaruh yang nyata. Hal ini diperkuat dengan hasil analisis tanah yang menunjukkan bahwa kandungan $\mathrm{N}$ dalam tanah setelah aplikasi pemupukan rendah yaitu hanya sebanyak $0.17 \%$ (Balittanah, 2014).

Pertambahan jumlah tunas (Gambar 3) lebih cepat berhenti dibandingkan pertambahan panjang tunas (Gambar 1). Tunas muncul serempak pada awal periode pertumbuhan tunas dan berangsur-angsur berhenti pertambahannya kemudian aktivitas pertumbuhan lebih fokus pada pemanjangan tunas. 


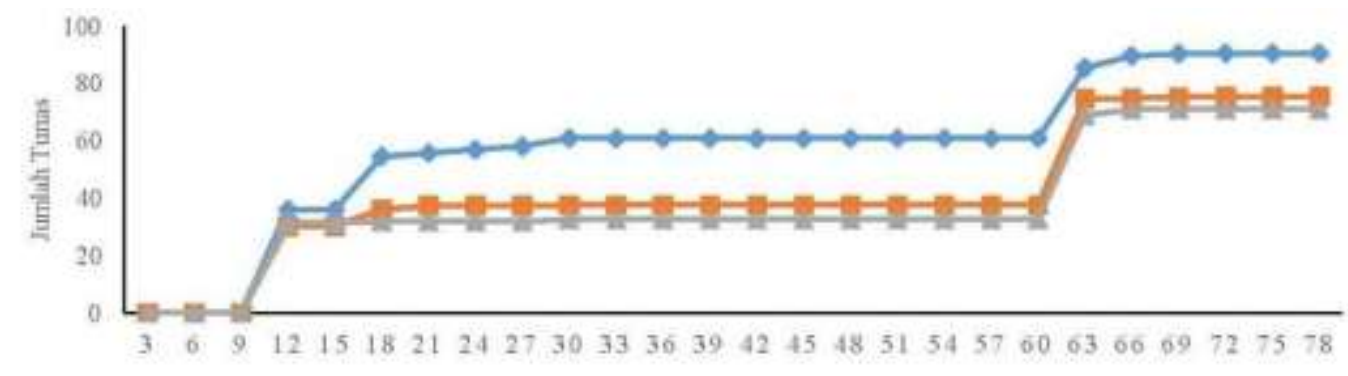

Hari Setelah Pemanplasam (HSP)

Gambar 3 Pengaruh perlakuan pemangkasan terhadap pertambahan jumlah tunas tanaman jeruk keprok Borneo Prima. Kontrol, - - Pangkas terbuka tengah, - Pangkas pagar

\section{Kehijauan Daun}

Tabel 3 menunjukkan bahwa perlakuan pemupukan nitrogen dan bentuk pemangkasan tidak memberikan pengaruh yang nyata terhadap tingkat kehijauan daun jeruk keprok Borneo Prima. Tingkat kehijauan daun yang diamati berkisar antara 64.7 sampai 67.8 yang berarti kandungan klorofil dalam daun cukup dan tidak kekurangan nitrogen. Hal ini tidak memberikan gambaran hasil pemberian pupuk dengan dosis yang berbeda dan menunjukkan bahwa jumlah nitrogen dalam tanah dan tanaman sama. Tidak berpengaruhnya perlakuan pemupukan nitrogen dipengaruhi oleh curah hujan yang tinggi selama penelitian. Curah hujan yang tinggi akan menyebabkan nitrogen mudah tercuci (Zaman et al., 2005 dan Hardjowigeno, 2010).

\section{Tinggi Tanaman}

Tanaman jeruk keprok Borneo Prima yang dijadikan bahan penelitian memiliki tinggi yang hampir sama saat penanaman. Setelah perlakuan pemangkasan bentuk, tinggi tanaman antar perlakuan berbeda nyata dan pada akhir periode tunas kedua, pemangkasan bentuk memberikan pengaruh yang nyata terhadap tinggi tanaman. Tanaman jeruk diharapkan memiliki tinggi yang rendah (pendek) sehingga memudahkan dalam perawatan dan pemanenan. Gardner et al. (2008) menjelaskan bahwa pertumbuhan ujung cenderung menghasilkan pertambahan tinggi sementara pertumbuhan laretal menghasilkan pertambahan lebar. Tanaman yang tidak dipangkas pertumbuhannya cenderung mengarah ke atas sehingga tanaman lebih tinggi sementara pangkas pagar dan terbuka tengah pertumbuhannya cenderung ke samping sehingga tanaman tidak terlalu tinggi, namun lebih lebar. Pemupukan nitrogen tidak memberikan pengaruh yang nyata terhadap tinggi tanaman jeruk keprok Borneo Prima. Pertambahan tinggi lebih dipengaruhi oleh banyaknya tunas-tunas baru yang muncul dan mengarah ke atas sehingga semua perlakuan memiliki potensi yang sama untuk memiliki tinggi yang sama karena memiliki tunas-tunas yang tumbuh ke atas.

\section{Luas Daun}

Tabel 3 menunjukkan bahwa pemupukan nitrogen tidak memberikan pengaruh yang nyata terhadap luas daun, sementara menurut Gardner et al. (2008), penambahan N meningkatkan pertumbuhan tanaman dan luas daun. Tidak berpengaruhnya $\mathrm{N}$ pada perlakuan pemupukan nitrogen diduga disebabkan oleh hilangnya $\mathrm{N}$ dalam tanah akibat pencucian karena curah hujan yang tinggi selama penelitian. Aziz et al. (2011) menyebutkan bahwa perlakuan pemupukan fosfor pada tanaman Centella asiatica secara signifikan meningkatkan jumlah total daun, panjang daun, jumlah total bunga dan ketebalan daun, sehingga ada unsur-unsur lain yang dibutuhkan tanaman tidak hanya unsur $\mathrm{N}$.

Perlakuan pemangkasan bentuk memberikan pengaruh yang nyata terhadap luas daun dengan daun terluas pada perlakuan tanpa pemangkasan. Tanaman yang dipangkas memiliki luas permukaan tajuk yang luas dan hampir semua bagian tanaman mendapat sinar matahari yang terik sementara tanaman yang tidak dipangkas memiliki tajuk yang rimbun sehingga cahaya matahari yang datang akan disaring oleh daun-daun yang bertumpuk. Daun tanaman yang kekurangan cahaya cenderung lebih luas tetapi lebih tipis (Gardner et al., 2008). 
Tabel 3. Kehijauan daun, tinggi tanaman, dan luas daun jeruk keprok Borneo Prima pada tiga bulan setelah perlakuan

\begin{tabular}{|c|c|c|c|}
\hline Perlakuan & $\begin{array}{c}\text { Kehijauan } \\
\text { daun }^{\mathrm{a}}\end{array}$ & $\begin{array}{l}\text { Tinggi } \\
\text { tanaman } \\
(\mathrm{cm})^{\mathrm{a}}\end{array}$ & $\begin{array}{c}\text { Luas } \\
\text { daun } \\
\left(\mathrm{cm}^{2}\right) \\
\mathrm{a}\end{array}$ \\
\hline \multicolumn{4}{|c|}{ Pemupukan Nitrogen } \\
\hline Kontrol & $64.7 \mathrm{a}$ & $82.9 \mathrm{a}$ & $16.3 \mathrm{a}$ \\
\hline $\begin{array}{l}\text { Di bawah } \\
\text { standar } \\
\text { rekomendasi } \\
(10 \mathrm{~g} \mathrm{~N})\end{array}$ & $67.5 \mathrm{a}$ & $85.7 \mathrm{a}$ & $14.4 \mathrm{a}$ \\
\hline $\begin{array}{l}\text { Standar } \\
\text { rekomendasi } \\
(20 \mathrm{~g} \mathrm{~N})\end{array}$ & $67.8 \mathrm{a}$ & $84.2 \mathrm{a}$ & $15.9 \mathrm{a}$ \\
\hline $\begin{array}{l}\text { Di atas } \\
\text { standar } \\
\text { rekomendasi } \\
(30 \mathrm{~g} \mathrm{~N})\end{array}$ & $65.8 \mathrm{a}$ & $86.2 \mathrm{a}$ & $16.0 \mathrm{a}$ \\
\hline \multicolumn{4}{|l|}{ Pemangkasan } \\
\hline Kontrol & $66.3 \mathrm{a}$ & $102.2 \mathrm{a}$ & $19.2 \mathrm{a}$ \\
\hline $\begin{array}{l}\text { Pangkas } \\
\text { terbuka } \\
\text { tengah }\end{array}$ & $66.7 \mathrm{a}$ & $81.0 \mathrm{~b}$ & $14.1 \mathrm{~b}$ \\
\hline $\begin{array}{l}\text { Pangkas } \\
\text { pagar }\end{array}$ & $66.4 \mathrm{a}$ & $71.0 \mathrm{~b}$ & $13.7 \mathrm{~b}$ \\
\hline Interaksi & tn & tn & tn \\
\hline $\begin{array}{r}\text { Keterangan: }{ }^{\mathrm{a}} \mathrm{An} \\
\text { yan } \\
\text { ber } \\
\mathrm{Du}\end{array}$ & $\begin{array}{l}\text { a-angka pad } \\
\text { diikuti oleh } \mathrm{h} \\
\text { da nyata pac } \\
\text { an's Multiple }\end{array}$ & $\begin{array}{l}\text { kolom y } \\
\text { uruf yang s } \\
\text { a taraf uji } \\
\text { Range Test) }\end{array}$ & $\begin{array}{l}\text { arg sama } \\
\text { ma tidak } \\
5 \% \quad \text { (uji }\end{array}$ \\
\hline
\end{tabular}

\section{Jumlah Daun}

Tabel 4 menunjukkan bahwa jumlah daun pada semua taraf perlakuan pemupukan nitrogen tidak berbeda nyata. Penjelasan sebelumnya mengenai jumlah tunas menunjukkan bahwa pemupukan nitrogen tidak memberikan pengaruh yang nyata sehingga setiap tanaman dianggap memiliki jumlah tunas yang tidak berbeda. Hal ini berkorelasi positif dengan jumlah daun yang tidak berbeda nyata pada semua perlakuan pemupukan nitrogen pada kedua periode tunas.

Tanaman jeruk yang tanpa pemangkasan (kontrol) memiliki jumlah tunas paling banyak pada periode tunas pertama dan tidak berbeda nyata dengan perlakuan lainnya pada periode tunas kedua, namun jumlah daun berbeda nyata pada kedua periode tunas. Hal ini lebih dipengaruhi oleh jumlah pertambahan daun. Pertambahan daun dari periode pertama ke periode kedua hampir sama pada semua perlakuan yaitu sebanyak 258.9 daun.

Perlakuan pemupukan nitrogen memberikan pengaruh yang nyata terhadap ILD pada periode pertama pertumbuhan tunas, namun tidak memberikan pengaruh yang nyata terhadap ILD pada periode pertumbuhan tunas kedua (Tabel 4). Perlakuan nitrogen di bawah standar rekomendasi dan sesuai standar rekomendasi memiliki luas daun terendah sehingga nilai ILD juga rendah. ILD sangat ditentukan oleh luas dan jumlah daun. Luas dan jumlah daun menentukan luas tajuk yang akan menutupi tanah.

Tabel 4. Jumlah daun dan Indeks Luas Daun (ILD) tanaman jeruk keprok Borneo Prima pada dua periode pertumbuhan tunas

\begin{tabular}{|c|c|c|c|c|}
\hline \multirow[t]{2}{*}{ Perlakuan } & \multicolumn{2}{|c|}{$\begin{array}{l}\text { Jumlah daun pada periode } \\
\text { pertumbuhan tunas ke- }{ }^{\mathrm{a}}\end{array}$} & \multicolumn{2}{|c|}{$\begin{array}{l}\text { Indeks luas daun pada periode } \\
\text { pertumbuhan tunas ke- }{ }^{\mathrm{a}}\end{array}$} \\
\hline & 1 & 2 & 1 & 2 \\
\hline \multicolumn{5}{|l|}{ Pemupukan Nitrogen } \\
\hline Kontrol & $468.8 \mathrm{a}$ & $664.4 \mathrm{a}$ & $1.0 \mathrm{a}$ & $1.1 \mathrm{a}$ \\
\hline Di bawah standar rekomendasi(10 g N) & $416.0 \mathrm{a}$ & $634.4 \mathrm{a}$ & $0.6 \mathrm{~b}$ & $1.0 \mathrm{a}$ \\
\hline Standar rekomendasi $(20 \mathrm{~g} \mathrm{~N})$ & $344.3 \mathrm{a}$ & $552.2 \mathrm{a}$ & $0.8 \mathrm{ab}$ & $1.1 \mathrm{a}$ \\
\hline Di atas standar rekomendasi (30 g N) & $132.0 \mathrm{a}$ & $703.7 \mathrm{a}$ & $1.0 \mathrm{a}$ & $1.2 \mathrm{a}$ \\
\hline \multicolumn{5}{|l|}{ Pemangkasan } \\
\hline Kontrol & $871.9 \mathrm{a}$ & $1048.8 \mathrm{a}$ & $1.4 \mathrm{a}$ & $1.4 \mathrm{a}$ \\
\hline Pangkas terbuka tengah & $228.3 b$ & $448.4 b$ & $0.7 b$ & $1.0 \mathrm{~b}$ \\
\hline Pangkas pagar & $197.2 \mathrm{~b}$ & $418.9 b$ & $0.5 \mathrm{~b}$ & $0.9 \mathrm{~b}$ \\
\hline Interaksi & tn & $\operatorname{tn}$ & tn & tn \\
\hline
\end{tabular}




\section{Indeks Luas Daun (ILD)}

Perlakuan bentuk pemangkasan memberikan pengaruh yang nyata terhadap ILD. Tabel 4 menunjukkan bahwa ILD tertinggi adalah pada perlakuan kontrol yaitu sebesar 1.4 di kedua periode pertumbuhan tunas. Tanaman yang tidak dipangkas memiliki jumlah daun lebih banyak dan luas okupasi lahan lebih tinggi dibandingkan tanaman yang dipangkas sehingga nilai ILD lebih tinggi. Tanaman yang dipangkas memiliki jumlah daun yang lebih sedikit akibat pemangkasan sehingga okupasi lahan lebih rendah dan nilai ILD rendah.

\section{Keragaan Tanaman Panjang Tajuk Arah Utara-Selatan dan Timur-Barat}

Perlakuan pemupukan nitrogen tidak memberikan hasil yang nyata terhadap panjang tajuk, karena panjang tajuk lebih ditentukan oleh tunas-tunas baru yang muncul. Gardner $e t$ al. (2008) menjelaskan bahwa per-tumbuhan ujung cenderung menghasilkan pertambahan tinggi sementara pertumbuhan laretal menghasilkan pertambahan lebar sementara pemupukan nitrogen lebih mem-pengaruhi banyaknya tunas yang muncul dan panjang tunas.

Tabel 5. Pengaruh terhadap panjang tajuk arah utara-selatan dan arah timur-barat pada dua periode pertumbuhan tunas

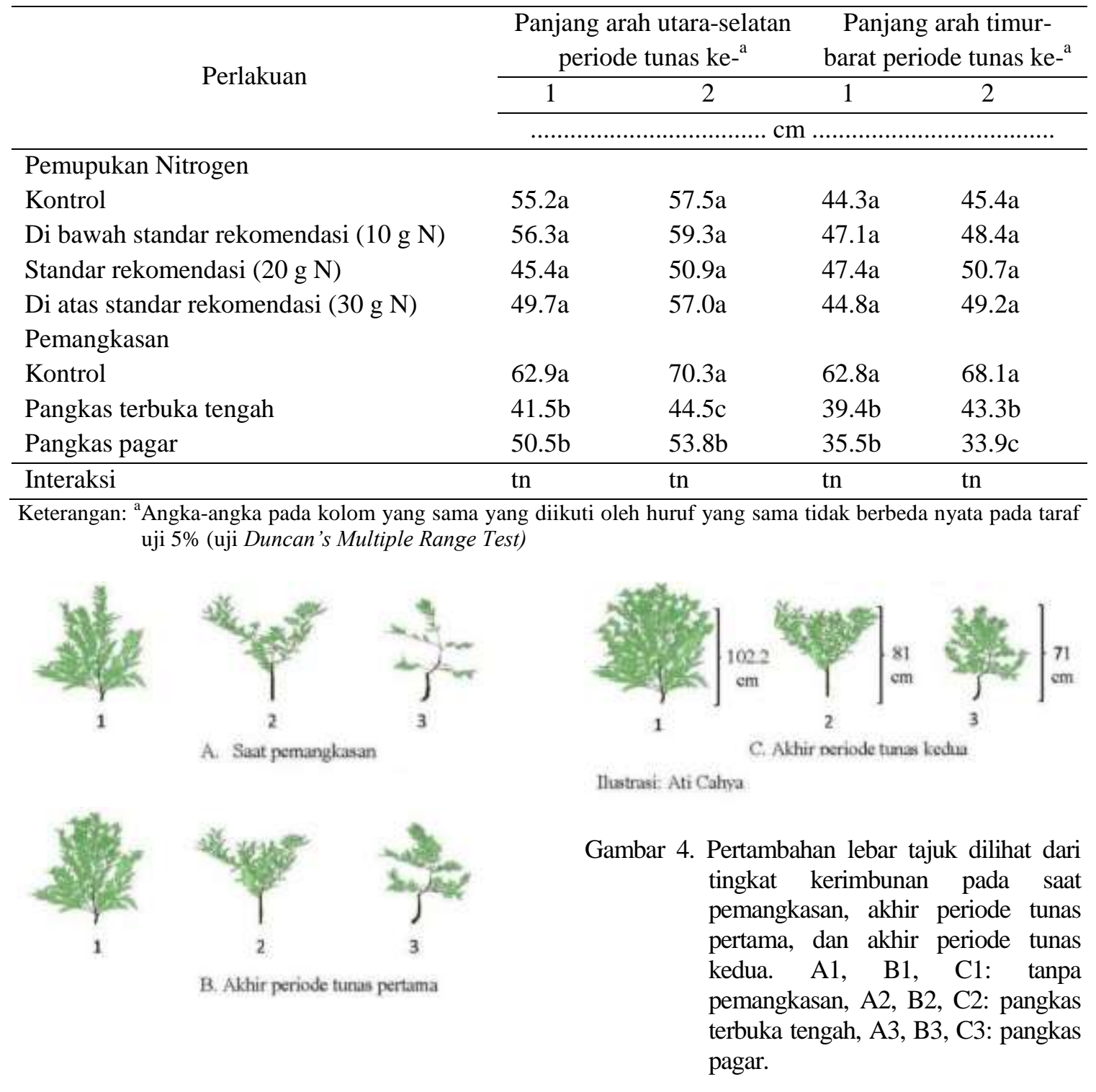


Panjang tajuk terus bertambah seiring bertambahnya jumlah tajuk dan panjang tunas. Perlakuan pemupukan nitrogen dan bentuk pemangkasan tidak memberikan hasil yang nyata terhadap pertambahan panjang tajuk. Gambar 4 menunjukkan bentuk keragaan tanaman jeruk keprok Borneo Prima pada saat setelah pemangkasan ( 0 hari setalah pemangkasan), akhir periode tunas pertama (39 hari setelah pemangkasan), dan akhir periode tunas kedua (78 hari setelah pemangkasan). Gambar tersebut menunjukkan perubahan panjang tajuk arah utara-selatan dan orientasi bentuk pemangkasannya. Bentuk tajuk pangkas pagar cenderung melebar, pangkas terbuka tengah cenderung bulat, dan kontrol cenderung tak beraturan.

\section{KESIMPULAN}

Perlakuan pemupukan nitrogen tidak memberikan pengaruh yang nyata terhadap pertumbuhan vegetatif dan keragaan tanaman. Pemangkasan terbuka tengah dan pagar menghasilkan panjang tunas pada periode ke 1 berturut-turut $8 \mathrm{~cm}$ dan $6 \mathrm{~cm}$, sedangkan pada periode pertumbuhan tunas kedua berturutturut $4 \mathrm{~cm}$ dan $5.4 \mathrm{~cm}$. Jumlah daun pada periode tunas ke 2 lebih banyak dibandingkan periode ke 1. Indeks luas daun pada periode pertumbuhan tunas ke 2 lebih tinggi dibandingkan periode ke 1. Pemupukan yang diberikan belum mampu menghasilkan keragaan vegetatif pada beberapa peubah pertumbuhan tanaman jeruk keprok.

\section{DAFTAR PUSTAKA}

Aziz, S.A., M. Ghulamahdi, A. Afrida. 2011. The effect of phosphorus fertilization on Indiana Pennyworth (Centella asiatica L. Urban) in high altitude. J. Hort. Indonesia. 2(1): 1-5.

[Balittanah] Balai Penelitian Tanah. 2014. Hasil Analisis Tanah. Balittanah. Bogor.
[BMKG] Badan Meteorologi Klimatologi dan Geofisika. 2014. Data Iklim Bulanan. BMKG. Bogor.

[BPPMD] Badan Perumahan dan Penanaman Modal Daerah. 2009. Prospek Menguntungkan Investasi Budidaya Jeruk Borneo Prima. Kalimantan Timur.

[BPS] Badan Pusat Statistik. 2013. Data Ekspor Impor. http://www.bps.go.id [diunduh 15 Juni 2014].

[BPS] Badan Pusat Statistik. 2014. Produksi Buah-buahan dan Sayuran Tahunan di Indonesia, 1995-2013. http://www.bps. go.id [diunduh 15 Juni 2014].

Dewi, I.S., G.S. JAwak, B.S. Purwoko, M. Sabda. 2014. Respon pertumbuhan kultur in vitro jeruk besar (Citrus maxima (Burm.) Merr.) cv. Nambangan terhadap osmotikum dan retardan. J. Hort. Indonesia. 5(1):21-28.

Gardner, F.P., R.B. Pearce, R.L. Mitchell. 2008. Fisiologi Tanaman Budidaya. Volume ke-1.

Hardjowigeno, S. 2010. Ilmu Tanah. Akademika Pressindo. Jakarta.

Pusat Data dan Sistem Informasi Pertanian. 2013. Buletin konsumsi pangan. Buletin Konsumsi Pangan. 04(01): 1-51.

Warta Prima. 2007. Varietas jeruk baru dari Rantau Pulung. Edisi Februari 2007. Warta Prima, Buletin Kemitraan PT Kaltim Prima Coal, Sengata.

Zaman, Q.U., A.W. Schumann, W.M. Miller. 2005. Variable rate nitrogen application in Florida citrus based on ultrasonically-sensed tree size. Applied Enginering In Agriculture. 21(3): 331335 . 